\title{
THE EFFECT OF INTEREST AND FOREIGN EXHANGE RATE ON MACROECONOMIC PERFORMANCE AND BANKING SECTOR
}

\author{
Assist. Prof. Dr. Yakup DURMAZ1', ZeynepDerya DÜŞÜN and Dr. Erkan Alsu
}

${ }^{1}$ Faculty of Economics Administrative and Social Sciences, Hasan Kalyoncu University, Havalimanı Yolu Üzeri 8. Km. Gaziantep, Turkey. Tel: 90-342-211-8080. E-mail: yakup.durmaz@hku.edu.tr and yakupdu@hotmail.com

${ }^{2}$ Akbank Branch Manager. E-mail: ddusun@hotmail.com

${ }^{3}$ Lecturer Gaziantep University ,OMYO , management organization, erkanalsu@gmail.com

\section{Abstract}

Financial authorities can form economic policies based on the relationship between interest and exchange rates. However, their success on this subject is controversial. In this study, the effect of interest and exchange rates on macroeconomic performance and banking sector will be discussed. The purpose of the study, in this context, is to demonstrate the effects of the relationship between interest and exchange rate. This is really important in terms of revealing the power of financial authorities.

Key Words: Interest Rate, Foreign Exchange Rate, Macroeconomic Performance, Banking Sector.

\section{Council for Innovative Research}

Peer Review Research Publishing System

\section{Journal: Journal of Social Sciences Research}

Vol. 10, No. 1

editor@jssronline.com

www.jssronline.com 


\section{INTRODUCTION}

The changes in exchange rates in open economies are one of the most important factors which affect the main economic indicators. Financial authorities try to affect the course of short term interest rates with the help of economic policies.

With increasing inclination to globalization, the importance of interest and exchange rates has increased in terms of macroeconomic performance. The changes in interest and exchange rates may have an effect on both financial and real sector. Nowadays, interest and exchange rates have merely become indicators for the foundations of sustainable development and stable economy. The changes in interest and exchange rates also influence the investment decisions of local and foreign companies and consumer expenditures. Therefore, financial authorities take these two variables into serious consideration while forming economic policies.

Developed and developing countries have shown great interest in exchange and interest rates in recent years. Under this interest, lies the effect of interest and exchange rates on macroeconomic variables (Sanchez, 2005: 8). The central bank can control exchange rate with the help of interest rate in exceptional situations. The interaction between interest and exchange rates are mainly happens in three ways (Sağlam and Yıldııım, 2007:11)

The first way is the increase in the demands for local financial assets as a result of a high rate of local inflation. In this way, exchange demand and the domestic currency value increase. In this case, investors demand local investment instruments until the interest rate parities are acquired. As for the second way, increasing interest rate causes a decrease in the profits of companies and banks since it raises the level of interest burden. This leads to retardation in the cash flow and an increase in the debt burden. Also, the problem of loan repayment arises. If loans are not repaid, bank balance sheets becomes spoiled and economic activity slows down, resulting in negative expectations. Therefore, domestic currency loses its value. Finally, in the last way, with the increase of interest rates, the interest burden in public finance and inflationary expectations also increase. This makes a way for a high rate of risk premium and a loss in the domestic currency value ( Sağlam ve Yıldırım, 2007: 12-13).

The purpose of this study is to examine the effects of the relation between interest and exchange rates. In this regard, the effect of the interaction between interest-exchange rates on macroeconomic variables (inflation, balance of payments, debts, financial growth, investments) and on banking sector will be explained. In the titles below, the effects of interestexchange rates will be discussed.

\section{1-) Interest- Exchange Rates and Inflationary Effects}

The relationship between interest-exchange rates and inflation are analyzed in the scope of International Fisher Effect (IFE). IFE explains that the differences in interest rates between countries are caused by the changes in those countries' expected inflation rates ( Şimşek and Kadılar, 2006:10). The Fisher Equation, which was named by an American economist Irving Fisher, explains the relationship between the interest rate and inflation.

According to Fisher there are two kinds of interests: nominal and real interests (http://muhasebeturk.org/ecopedia/388$\mathrm{f} / 36883$-fisher-denklemi-nedir-ne-demek-tanimi-anlami.html). Nominal and real interest rates differ from each other in terms of inflation rate. If, for some reason, financial authorities increase the demand for money, nominal interest rates will fall. This causes a boom in the economy and, hence, a raise in the inflation. This way, interest rates also increase in the long term with the increasing rate of inflation. In other words, monetary expansion, inflation and interest rates go up at the same time in the long run (http://www.ekometre.com/2/kur-faiz-ve-enflasyon-iliskisi-uzerine-bir-deneme.html) . In the Fisher equation, the relationship between nominal and real interest ( $r=i-\pi)$ rates affects exchange rates as well (Yılancı, 2009: 8).

According to the Fisher Effect, the difference between nominal interest rates of different countries will be equal to the difference between expected exchange rates of these countries (Utamiandlnanga, 2009: 15). The mathematical representation of the equation is given below.

ITR - IUS $=E(S)-S / S$

The left side of the equation shows the difference between nominal interest rates, while the right side of the equation shows the expected change in the exchange rate. This is generally known as International Fisher Effect, which has been generalized by purchasing power parity (ppp). According to relative ppp, the changes in exchange rates between two countries are formed by the differences of inflation rates between these countries. Generalized Fisher Effect, on the other hand, explains the expected changes in exchange rates according to the difference between nominal interest rates. If we put these all together (Seyidoğlu, 2003: 359-360):

PTR - PUS $=$ ITR - IUS $=E(S)-S / S$

The last equation demonstrates the interest-exchange and inflation rates between countries more clearly. In other words, the equation shows that the countries which have a high rate of inflation also have a high rate of interest and exchange rates. In this case, the forward rate is at a premium (Seyidoğlu, 2003: 360).

\section{2-) Interest - Exchange Rates and Borrowing}

The relation between interest and exchange rates is much more effective when public debt stock consists of foreign exchange indexed assets. Although, depending on this effect, public debt stock increases in a very short time, risk level 
and maturity structure is affected negatively by this situation (http://www.integralforex.com.tr/enflasyon-faiz-ve-dovizkurlari-arasindaki-iliski).

Debts of developing countries do not involve local currency and they are not long-term loans. They are more likely to be short-term loans and in the form of foreign currency, creating a debt crisis with high interest rates(IMF, 2004: 7). With the decrease of sensitivity of debt stock to interest and exchange rate, debt structure gets much better. This eliminates the fact that government debt being a potential risk for the local economy. This helps local economy become stronger (http://acikekonomi.com/2014/08/05/kur-ve-faiz-iliskisi-uzerine). Structural deformities in the debt stock create a risk in the budget. Therefore, many countries arrange their public (government) debt stock considering cost and risk characteristics of different debt structures. However, countries cannot always fulfill the borrowing strategies according to their wishes (https://www.ekodialog.com/Konular/borc stoku borc yuku.html). The course of economy, risk perception of investors and their reluctance regarding lending to public sector, eliminate the effectiveness of public debt management. This is called as the "Original Sin" in economy (Gürcihan ve Yılmaz, 2007: 26). This concept was first used in economical sense by Eichengreen and Hausmann in 1999. Kahn defines it as "inborn sin". In this regard, countries having trouble in finding loan, cannot borrow money in the long term from neither local nor foreign markets. They become indebted on the condition that their borrowings are short-term and with high interest rate (Kahn, 2005:21).

The debt structure of countries affects their economical performance. A sudden increase in a country's public debt level may cause a great deal of harm ( Gürcihan and Yılmaz, 2007: 27). The basis for economic stabilization is formed maintainable public debt and with well-prepared financial policies. The rate of public debt service and debt capacity are affected by the level of debt stock and structure (http://www.ekohaber.com.tr/ekohaber-prof-dr-ilker-parasiz-19-yazi id7815.html). A debt structure in foreign currency with short term floating interest rates is considered risky since it makes debt service vulnerable against interest and exchange activities (http://www.borsagundem.com/makro-ekonomi/kisavadeli-dis-borc-stoku-azaldi-688027.htm). If a debt stock needs to be translated in foreign currency, then the problem is much bigger due to the fact that the government in question cannot make a borrowing in foreign currency form since the investors are reluctant in the topic and there is insufficient amount of foreign exchange in the market. Moreover, domestic currency loses its value in the exchange market. Should this situation last longer, the central bank reduces its reserves (http://www.sabah.com.tr/ekonomi/2011/06/20/turkiyenin-borc-stogThe u). An unhealthy debt structure, in terms of maturity structure and currency characteristics, plays an important role in the outbreak and expansion of a financial crisis.

Whether it is public or private, if a country's debt cannot be paid then an external debt crisis occurs. In developing countries it slows down the financial development process and increases the economic problems. Macro-economical instabilities and financial weaknesses enhance the rate of economic fragility, especially in the process of liberalization. The characteristics of fragile economic structures are;

$>$ The increase in debt financing

Transition from long term debt to short term debt

$>$ The increase in speculative activities in asset markets

What deepens the economic crisis more is the disappearance of the "trust" in banks and in the protection of deposits.

\section{3-) Real Effects of Interest and Exchange Relation}

As a result of low foreign exchange rates and high interest rates in real measures, the competitive power of the economy weakens. In order not to cause a financial crisis because of the high interest rates, the costs are kept under pressure. After national interest and exchange rates became very much contingent upon the capital movements, national economy policies have began not to serve the economic and social purposes (http://www.integralforex.com.tr/enflasyon-faiz-vedoviz-kurlari-arasindaki-iliski). As the result of the over valuation of the domestic currency, current deficit gets bigger. Therefore the interest rates go up with the cost of financing the public deficit. This leads a way for an economical structure in which financial transactions are prominent because of the low level of investment and production. National economy policies have grown into a system only interested in controlling the capital flows rather than maintaining the macroeconomic stability and growth. This causes a reduction in production and employment capacity ( Paşaoğlu. 2000:88-89)

In GDP calculations, gross fixed capital reflecting the physical investment expenditure of public and private sector is very important in terms of economic growth. That is, the effect of the relationship between interest and exchange rates on the growth rate first shows itself in investments.

\section{4-) Interest and Exchange Rates and Balance of Payments}

Balance of payments is a macroeconomic indicator affected by the interaction of interest and exchange rates. This can be seen by observing the effect of foreign trade and portfolio balance. In open economies, the interest and exchange policies may have an either positive of a negative effect on the balance of payments (http://www.mahfiegilmez.com/2013/01/ekonomideki-iliskiler-ve-celiskiler.html).

The relationships between interest and exchange rates which depend on the capital movement have caused adverse events in developing countries, especially in foreign trade flows. These capital flows are mainly speculative, causing instability (macroeconomic) and, therefore, foreign trade deficit (Helleiner, 1998:24). As a consequence of the valuation of foreign exchange rate, export sector is obliged to reduce the production. Hence the foreign trade balance is affected negatively by this situation (http://www.econturk.org). 
The changes in import and export sectors following the low and over valuation policies are considered very important in order for the exchange policy to show expected results on the foreign trade stability (Zengin, 2001: 41). Fixed rate policy is not flexible, obviously, against economic shocks. Thus, policy makers try to maintain the exchange rate by increasing the interest rates. However, this practice comes at a price since high interest rate unbalances the balance of payments. In Turkey, especially in the period before the 2001 economic crisis, the increase in the energy prices and the high interest rates raise the cost of maintain the exchange rate. Moreover, the increasing interest rates not only caused a decrease in the export but also caused a growth in the import (Kansu ve Baydur, 2008: 37).

\section{5-) Interest - Exchange Rates and Banking Sector}

In 1970s and 1980s different kinds of economic crisis emerged in the different parts of the world. Crisis models have been developed so as to explain the reasons for these economic crises. One of them is First Generation Crisis Model developed by Paul Krugman. According to this model, in countries where fixed exchange rate regime is applied, governments finance their budget deficits by monetizing (http://www.esfenderkorkmaz.com/arastirma-yazilari/kuresel-kriz-turkiye-ye-etkileri-vecozum-onerileri.html). Since the domestic currency loses its value in this way, the central bank sells foreign currency in order to maintain the foreign exchange rate. This causes international reserves to decrease. In this case, speculators immediately purchase foreign currency using national currency (Krugman, 1979:311-312). Should the central bank doesn't have enough reserves to prevent these speculative attacks; it becomes indebted to the foreign countries. This happens at the cost of increasing the interest rates, unless of course, the central bank takes necessary precautions.

\section{6-) Foreign Exchange Risk}

One of the important reasons for the fluctuations in foreign exchange rates is the differences between the interest rates of countries. Sudden changes in exchange rates, reflects on the bank balance sheets and on the market price of exchange offices. Banks' profits also change with the fluctuations in the exchange rate. If the foreign currency assets and liabilities are not equal to each other, then exchange rate risk emerges with regards to the balance sheets (Russ, 2007: 29-30). The difference between assets and liabilities is caused by the banks' desire of making a profit based on the exchange rate expectations. Therefore it is a must for banks to check the foreign currency positions on a regular basis. Both foreign exchange and interest rates reach a balance based on the economic parameters, such as fiscal and monetary policies, inflation, investment and growth policies and balance of payments. Central banks interfere in the foreign exchange markets so that they can check exchange positions, reach the targeted exchange rate and manage the reserves and foreign debts (Okay, 2002: 49-50).

Foreign exchange risk is measured by calculating the net risk exposure of a bank and exchange positions in the banks' portfolio. We can express it as; Net Risk= (Exchange assets - Exchange liabilities) + (Exchange sale - Exchange purchase). Another way to measure the exchange risk is to use exchange volatility as a base. The net risk of exchange in the form of domestic currency goes up with the increasing rate of fluctuation in foreign exchange rate. The fluctuation rate in foreign exchange rate also affects the foreign exchange supply and demand. Exchange prices change directly proportionate to the demand for exchange rate. In other words, if the demand for exchange rate increases, foreign exchange changes against the domestic currency. Likewise, when the supply for the exchange decreases, the exchange rate increases in the country's favor (Aloğlu, 2005: 57-59).

After the 1997 Asian crisis, one of the discussion topics was the stabilization policy to adopt against the possible volatility in the national currency value. In this regard, IMF claimed that the high interest rates may prevent the possible value loss in the domestic currency. This way, local assets would become valuable and the rate of foreign capital inflows would increase. On the other hand, objectors of IMF stated that the high interest rates caused an economic recession, and therefore may lead to an economic crisis (Zanna, 2005:75-77).

The fluctuations in the international interest rates increase the fund costs of developing countries. The relative importance of investments may also change depending on this case. If the foreign capital is not sterilized enough, deposits of banks skyrocket and become less reliable. For example, during South Asia crisis, due to not enough absorption of foreign capital by open market operations, banks directed their funds towards risky investments. At the end of the expansionary process, the reasons for instability also affect the financial system. The fact that the foreign capital leaves the country due to the chaos and loss of trust in marketplaces causes an unexpected fall in bank deposits and harms bank assets. Real exchange rate fluctuations cause a direct loss in banks- in the event of maturity and exchange rate mismatch between bank liabilities and assets- and an indirect loss in the number of bank customers. Researches show that the high rate of instability in inflation, increase in the real exchange rates and devaluation risk enhance the bank liabilities. Hence the vulnerability is increased (Çinko ve Ak, 2009: 98-101).

\subsection{Market Risk}

The increasing inflation rate at the beginning of the 1970s affected the currency markets in a negative way. Financial institutions gave a start to byproduct transactions so as to protect themselves from these fluctuations. After 1970, there has been an instrument abundancy in the market. There have also been structural changes in the global banking system. Namely, a lot of financial institutions have obtained global qualifications as a result of merging of big banks. Hence, local authorities who are arranging the financial activities have removed the restrictions against financial institutions. In this way, competition in world banking sector has gotten fierce with new productions. Furthermore, the developments in communication and information technologies have made way for an increase in transaction volume of bank byproducts and in the possible market risks (Akan, 2007:87-89). 
Up until the 1990s, market risk was in the background in contrast to credit risk. It only became a current issue for the Committee (Basel Committee on Banking Supervision), when integration in financial markets gained speed. Main framework of Basel I Accord which predicted a capital allocation for the market risk was issued in 1993. In this framework, statements like "banking transactions" were used to express the operations performed by banks. Also, capital requirements were imposed for the market risk (Ayan, 2007: 74-76). Moreover, the fluctuations in interest and exchange rates are mentioned to be possible risk factors (BCBS, 1993: 3 ).

Market risk is defined as the risk a bank may face when it loses money or capital. Credit risk formed a basis for Basel I Accord and considered to be the most important risk in 1980s. However, in the years after that, a great number of American financial institutions were on the verge of bankruptcy because of the interest and exchange rate fluctuations. In order to make up this deficiency, capital sum was added to the capital adequacy ratio $(\mathrm{CAL})$ [ $C A L=$ Capital Equity / Risk weighed assets] (Teker et al., 2005:57-58).

\subsection{Credit Risk}

Credit risk is one of the oldest risks banks are exposed to. It increases in the times of an economic crisis or a recession. It is briefly defined as a debt that a borrower is failed to pay. Especially banks which perform their transactions with foreign currency assets pose a risk for both themselves and the markets (Anbar, 2006:73).

Deposits of banking systems in developing countries are short termed. These countries also have a high rate of transactions in foreign currency. In the period after devaluation, banking systems of these countries are affected negatively by both the exchange risk and the increase in the interest rates. Furthermore, banks have the problem of liquidity squeeze because of the short term debts. On the other hand, in the event of devaluation, debt amount of local companies go up whereas their receipts remain stable (Kaplan, 2002:120-122).

\section{CONCLUSION}

The measurement for a country's economic state is its macroeconomic performance. Surely policy makers have the biggest part in forming the macroeconomic performance of a country. Outward countries are affected by the developments in both local and abroad. These effects can be seen in the macroeconomic performance. Policy makers may have to use the interest rates to prevent negative outcomes. The changes in interest rates may also alter the exchange rates. The fluctuations in exchange rates, therefore, have an impact on macroeconomic variables, such as inflation, financial growth, balance of payments, debt structure and banking sector. This issue is crucial considering the global world economy. Thus, financial authorities should take interest and exchange rate fluctuations into serious consideration. To be able to minimize the negative effects of interest-exchange rate relationship on macroeconomic performance, policy practitioners need to take precautions regarding balance of payments, banking sector, fiscal discipline and price stability.

\section{REFERENCE}

Akan, N.Burak (2007), "Piyasa Riski Ölçümü”, Bankacılar Dergisi

Aloğlu Ziya Tunç, (2005), "Bankacılık Sektörünün Karşılaştığı Riskler ve Bankacılık Krizler Üzerindeki Etkileri” Uzmanlık Yeterlilik Tezi, Ankara,T.C. Merkez Bankası Bankacılık ve Finansal Kuruluşlar Genel Müdürlüğü

Anbar, Adem (2006), "Credit Risk Management InTheTurkishBankingSector : ASurveyStudy", Elektronik Sosyal Bilimler Dergisi www.e-sosder.com ,

Ayan, Ebubekir (2007), "Türkiye'de Bankacılık Risklerinin Yönetiminde Basel-II Uzlaşısı ve Faiz İle Kur Risklerine İlişkin Bir Uygulama”, (Basılmamış Doktora Tezi, Kocaeli Üniversitesi Sosyal Bilimler Enstitüsü

BasleCommittee on BankingSupervision "TheSupervisoryTreatment Of Market Risks" ConsultativeProposal , Basel: (April-1993)

Başoğlu, Ufuk (2000), "Fınanasal Serbestleşme ve Uluslararası Portföy Yatırımları”, Balı-kesir Üniversitesi Sosyal Bilimler Enstitüsü Dergisi, 3(4)

Çinko, Levent ve Rengin Ak (2009), “Küreselleşen Ekonomilerde Yaşanan Bankacılık Krizlerinin Anatomisi”, Maliye Finans Yazları

Fischer, Stanley (2001), "Exchange Rate Regimes: Is theBipolarViewCorrect?”, Journal of EconomicPerspectives,

Gürcihan, Burcu ve Erdal Yılmaz (2007), "Türkiye'de Kamu Borç Stokunun Yapısı: Orijinal Günah Göstergeleri ve RiskDahil Kamu Borç Yükü”, İktisat İşletme ve Finans, Bilgisel Yayınçılı

IMF, (2004), “SovereignDebtStructureforCrisisPrevention", PreparedbytheResearchDepartment

Kahn, Brian (2005), "Original Sin and Bond Market Development in Sub-SaharanAfrica”, From: Africa in the World Economy - TheNational, Regionaland International ChallengesFondad, TheHague, www.fondad.org

Kansu, Aydan ve Cem Mehmet Baydur (2008), "Faiz Düzeyinin Döviz Krizini Önlemedeki Rolü: Türkiye Şubat 2001 Krizinin Değerlendirilmesi”, Gazi Üniversitesi İktisadi ve İdari Bilimler Fakültesi Dergisi 


\section{ISSN 2321-1091}

Kaplan, Cafer (Haziran-2002), "Bankacılık Sektörünün Yabancı Para Pozisyon Açığı: Türkiye Örneği” Türkiye Cumhuriyet Merkez Bankası, Araştırma Genel Müdürlüğü Çalışma Tebliği

Krugman, Paul (1979), "A Model of Balance-of-PaymentCrises”, Journal of Money, CreditandBanking, 11(3)

Okay, Esin (Aralık-2002), "Türk Bankacılık Sektöründe Risk ve Kriz”, İstanbul Ticaret Üniversitesi Dergisi

Sağlam, Yıldız ve Mehmet Yıldırım (2007), "2001 Krizi Sonrası Uygulanan Faiz ve Kur Politikalarının Türkiye Ekonomisine Etkileri”, Adnan Menderes Üniversitesi ve Avrupa Araştırmalar Merkezi, Güncel Ekonomik Sorunlar Kongresi'ne Sunulan Bildiri

Seyidoğlu, Halil (2003), Uluslararası İktisat Teori Politika ve Uygulama, 15. Baskı,İstanbul: Güzem Can Yayınları

Teker, Suat K.Evren Bolgün ve M.Barış Akçay (2005), "Banka Sermaye Yeterliliği: Basel II Standartlarının Bir Türk Bankasına Uygulanması", Elektronik Sosyal Bilimler Dergisi, 3(12)

Ural, Mert (2003), "Finansal Kırılganlık - Kriz - Türkiye”, Dokuz Eylül Üniversitesi, İ.I.B.F.Dergisi, 18(1)

Yalçın, Ebru (2005), “iktisadi Büyüme ve Dış Krediler: Ampirik Bir Çalışma”, Uzmanlık Yeterlilik Tezi, T.C. Merkez Bankası Dış İlişkiler Genel Müdürlüğü, Ankara

Yılancı, Veli (2009), "Fisher Hipotezinin Türkiye İçin Sınanması: Doğrusal Olmayan Eşbütünleşme Analizi”, Atatürk Üniversitesi İktisadi ve İdari Bilimler Dergisi, 23(4)

Zanna, LuisFelipe (2005), "FightingAgainstCurrencyDepreciation, MacroeconomiclnstabilityandSuddenStops", University of Pennsylvania, Board of Governors of the Federal ReserveSystem International Finance DiscussionPapers

Zengin, Ahmet (2001), "Reel Döviz Kuru Hareketleri ve Dış Ticaret Fiyatları (Türkiye Ekonomisi Üzerine Ampirik Bulgular)”, Cumhuriyet Üniversitesi İktisadi ve İdari Bilimler Dergisi, 2(2)

http://acikekonomi.com/2014/08/05/kur-ve-faiz-iliskisi-uzerine

http://www.borsagundem.com/makro-ekonomi/kisa-vadeli-dis-borc-stoku-azaldi-688027.htm

http://www.econturk.org

https://www.econ.berkeley.edu

https://www.ekodialog.com/Konular/borc stoku borc yuku.html

http://www.ekohaber.com.tr/ekohaber-prof-dr-ilker-parasiz-19-yazi id-7815.html

http://www.ekometre.com/2/kur-faiz-ve-enflasyon-iliskisi-uzerine-bir-deneme.html

http://www.esfenderkorkmaz.com/arastirma-yazilari/kuresel-kriz-turkiye-ye-etkileri-ve-cozum-onerileri.html

http://www.integralforex.com.tr/enflasyon-faiz-ve-doviz-kurlari-arasindaki-iliski

http://www.mahfiegilmez.com/2013/01/ekonomideki-iliskiler-ve-celiskiler.html

http://muhasebeturk.org/ecopedia/388-f/36883-fisher-denklemi-nedir-ne-demek-tanimi-anlami.html

http://www.sabah.com.tr/ekonomi/2011/06/20/turkiyenin-borc-stogu 